\title{
GENERATYVUMO PERSPEKTYVA VYRESNIO AMŽIAUS SUAUGUSIŲJŲ MOKYMESI: LITERATŪROS APŽVALGA
}

\author{
Salomëja Šatiene \\ Klaipédos valstybine kolegija \\ DOI: https://doi.org/10.52320/svv.v0iVI.203
}

\begin{abstract}
Anotacija
Šiame straipsnyje, remiantis įvairių šalių mokslinès literatūros šaltiniais, analizuojamas vyresnio amžiaus žmonių savaiminis mokymasis generatyvumo kontekste. Analizuojant generatyvumo ir vyresnio amžiaus suaugusiujų mokymosi sąsajas, siekiama atskleisti kaip generatyvumo kontekstas formuoja vyresnio amžiaus žmonių savaimini mokymąsi. Literatūros apžvalga leido išskirti generatyvumo kontekste vykstančio mokymosi būdingus bruožus, apimančius mokymąsi įtakojančius veiksnius, pagrindinius mokymosi proceso ypatumus ir mokymosi reikšmę vyresnių žmonių gyvenimui. Vyresnio amžiaus žmonių įsitraukimas ị generatyvumą, ankstesnio mokymosi kompetencija ir socialinè aplinka daro ịtaką mokymuisi. Generatyvumo kontekste vykstančio vyresnio amžiaus suaugusiujų mokymosi procesui yra būdinga informuotu dalyvavimu grịsta motyvacija, igalinimas, savaiminio mokymosi patirčiu ịvairovè, refleksija. Asmenybès augimas, asmeninès kompetencijos tobulinimas, savo vaidmens įtvirtinimas yra mokymosi pasekmės, darančios ịtaką vyresnių suaugusiujų gyvenimui.
\end{abstract}

Raktiniai žodžiai: generatyvumas, vyresnio amžiaus suaugusieji, mokymasis vyresniame amžiuje.

\section{Ivadas}

Temos aktualumas. Pastaraisiais dešimtmečiais išryškèjusi aktyvaus šiuolaikinès vyresnio amžiaus žmonių kartos įsitraukimo ị ekonominius ir socialinius procesus šeimos, bendruomenès ir visuomenès lygmenyse tendencija paskatino naują požiūrį edukacinès gerontologijos teorijoje siejamą su generatyvumu vyresniame amžiuje. Vyresnio amžiaus žmonių mokymąsi tiriančioje literatūroje teigiama, kad generatyvumas gali būti vertinamas kaip asmenybès augimo kontekstas (Narushima, 2004; Tam, 2013), sudarantis galimybes vyresnio amžiaus žmonèms savo žiniomis ir patirtimi prisidèti prie socialinès aplinkos (Ranzijn, 2002). Aktyvi ir produktyvi veikla reikalauja atitinkamų kompetencijų, kurios kyla iš naujų žinių igijimo bei igūdžių tobulinimo naujo tipo veikloje. Šią veiklą skatina ị ateitị orientuotos ilgalaikès vertybès, siejamos su socialinio konteksto tobulinimu ir gerinimu (Villar, 2012; Duguid et al., 2013).

Vyresnio amžiaus suaugusiųjų mokymosi teorija iš esmès remiasi vyresnio suaugusiojo amžiaus kaip raidos etapo konceptu, siejamu su vėlyvuoju gyvenimo laikotarpiu, kuriam būdingas vyresnis amžius $(50+)$ ir darbo karjerą baigusio asmens socialinis statusas. Žmogaus raidos teorijos, ir ypač Eriksono (1963) sukurta gyvenimo etapų teorija, jau beveik prieš šešis dešimtmečius tapo pagrindu tiriant vyresnio amžiaus suaugusius. Remiantis psichosocialinès raidos uždaviniais, kuriuos turi igyvendinti individai, ši teorija sieja vyresnị amžių su „generatyvumo“ ir ,integralumo“ (angl. generativity, integrity) sąvokomis. Paskutiniaisiais gyvenimo etapais individas patiria itampą tarp „generatyvumo“, reikalaujančio po savęs palikti kažką ateities kartoms, ir „stagnacijos“. Šią ịtampą individas gali išspręsti naujai apmąstydamas savo patirtị, ir ugdydamas išmintị (Erikson et al., 1986). Eriksonas ịvedè generatyvumo sąvoką kaip vidurinio suaugusiojo amžiaus aspektą, tačiau vẻlesni moksliniai darbai parodè, kad jis taip pat pasireiškia jaunesnio ir vyresnio suaugusiojo amžiaus etapuose su būdingais atitinkamo etapo raiškos ypatumais (Kotre, 1998), ir gali tapti ypač aktualus suaugusiojo gyvenime jam senstant (McAdams ir St Aubin, 1992).

Remiantis Eriksono teorija, mokymasis slypi vyresnio amžiaus žmogaus pastangose išspręsti raidos krizę siejamą su generatyvumo sąvoka, ir veda prie asmenybės augimo. Raidos etapo konfliktu ir ịtampų sprendimas vyresniame suaugusiojo amžiuje gali tapti tobulëjimo šaltiniu ir formuoti išminti (Erikson et al., 1986). Mokymasis visą gyvenimą vaidina lemiamą vaidmeni generatyviam įsitraukimui ì visuomenès gyvenimą (Erikson et al., 1986). Remiantis šiuolaikine moksline literatūra, mokymosi prasmė ir patirtis išryškèja ịvairiose su generatyvumu siejamose veiklos sferose apimančiose mokymą ir mentorystę (Stergios ir Carruthers, 2002; Kleiber ir Nimrod 2008; Golding ir Foley, 2017; Warburton ir Gooch, 2007), politini ir pilietini įsitraukimą (Field, 2003; Kleiber ir Nimrod, 2008; Jones ir McAdams, 2013; Narushima, 2004; Schugurensky ir Myers, 2008; Serrat et al., 2016; Lear, 
2013), produktyvią veiklą (Lysack ir Steipke, 2002; Kruse ir Schmitt, 2012; Borrero ir Kruger, 2015; Yuan et al., 2018), buvimą seneliais (Bates ir Goodsell, 2013), savanorystę (Birrer-Hardwick ir Greenwood, 2017; Narushima, 1999, 2000, 2005; Piercy et al., 2011), socialini dalyvavimą (Flynn, 2001; Krašovec ir Gregorčič, 2017; Urrutia et al., 2009). Generatyvumas ir grandgeneratyvumas gali pasireikšti kaip „,vidinis potraukis, kuris turi būti išreikštas“ (Ranzijn, 2002, 42 p.) ir investavimas i ateities kartas (Krašovec ir Gregorčič, 2017), galintis atsispindèti įvairiomis formomis. Kaip savo gyvenimo patvirtinimas indèliu ị pasauli jis gali būti išreikštas žinių ir išminties perdavimu sekančiai kartai (Golding ir Foley, 2017; Tabuchi ir Miura, 2015), socialiniu aktyvumu (Narushima, 2004), naratyvu apie altruizmą ir pasiaukojimą (Tabuchi ir Miura, 2015). Pastarujų dešimtmečių edukacinès gerontologijos srities empiriniuose tyrimuose generatyvumas vertinamas kaip neatsiejamas mokymosi vyresniame amžiuje aspektas (Narushima, 1999, 2000, 2004; Villar et al., 2012; Lear, 2013; Serrat et al., 2016). Deja, suaugusiųjų mokymosi generatyvumo kontekste reiškinys dar mažai analizuotas mokslinèje edukologijos srities literatūroje.

Tyrimo problema. Šiame darbe, remiantis pastaraisiais dešimtmečiais publikuotais darbais, skirtais vyresnio amžiaus suaugusiųų generatyvumo ir savaiminio mokymosi tyrimams, siekiama atskleisti kaip generatyvumo kontekstas formuoja vyresnio amžiaus žmonių savaiminị mokymąsi.

Tyrimo objektas - generatyvumo ir vyresnio amžiaus suaugusiujų mokymosi sąsajos.

Tyrimo tikslas - atskleisti generatyvumo raišką vyresnio amžiaus žmonių mokymesi teorinèje ir empirinejje literatūroje siejančioje generatyvumą su mokymusi vyresniame amžiuje.

\section{Tyrimo uždaviniai:}

1. Nustatyti pagrindinius generatyvumo sąlygotus veiksnius, turinčius ịtakos mokymuisi vyresniame amžiuje.

2. Išskirti pagrindinius generatyvumo kontekste vykstančio mokymosi proceso komponentus.

3. Atskleisti mokymosi generatyvumo kontekste reikšmę vyresnio amžiaus žmonių gyvenime.

Tyrimo metodai. Literatūros apžvalga buvo atlikta siekiant atskleisti šiuolaikines perspektyvas analizuojant generatyvumą kaip mokymosi vyresniame amžiuje kontekstą. Literatūros apžvalga leidžia išanalizuoti esamą žinių būklę, ir nustatyti tyrimų prioritetus (Grant \& Booth, 2009). Anglų kalba publikuotų literatūros šaltinių paieška apėmė šias elektronines duomenų bazes: EBSCOhost, ScienceDirect,Taylor and Francis. Raktiniai žodžiai apėmė tris kategorijas: (1) mokymasis (angl. "learning") (taip pat "personal development", "growth”, "competence development"), (2) vyresni suaugusieji (angl. "older adult"), (3) generatyvumas (angl. "generativity"). Taip pat buvo ịtraukti kiti vyresnius suaugusius ivardijantys galimi terminai (angl. „elderly”, „third age”, „later life”, „older adulthood”, „older people”). Žodžių paieška apėmè pavadinimus, raktinius žodžius ir santraukas. Publikacijų atrankos kriterijai: spausdinamas recenzuojamame moksliniame žurnale; parašytas anglų kalba; publikavimo laikotarpis 1999 - 2019 metai. Pirmajame paieškos etape buvo atrinktos 93 publikacijos. Tolesnè atranka apėmè du kriterijus: (1) empirinis vyresnio amžiaus žmonių (50+) tyrimas; (2) savaiminis mokymasis (angl. "informal learning"). Šiame etape paieškos rezultatas buvo 23 publikacijos. Nebuvo atrinkti darbai analizuojantys vyresnių žmonių įsitraukimą i generatyvumą be nuorodos ị asmeninị tobulejjimą ar mokymąsi.

\section{Generatyvumo veiksniai, darantys įtaką vyresnių žmonių mokymuisi}

İsitraukimas i generatyvumą. Mokslininkai, tyrinejjantys generatyvumą psichosocialinėje perspektyvoje ịsitraukimą i generatyvumą sieja su vyresnio žmogaus siekiu palikti palikimą ateinančioms kartoms (McAdams et al., 1998). Žmogiškujų vertybių, tradicijų ir kultūros išsaugojimas tarnauja kaip stiprūs gyvenimo prasmès vyresniame amžiuje šaltiniai (Pinquart, 2002). Jones ir McAdams (2013) teigia, kad suaugusiųų rūpinimasis ir indèlis ị ateities kartų gerovę pasireiškia kaip generatyvumo raidos antecedentai ịsitraukiant ị politinę ir pilietinę veiklą. Warburton ir Gooch (2007) atskleidè, kad vyresni žmonès yra linkę susieti savo veiksmus su ilgalaike ateitimi bei poreikiu palikti ilgalaiki palikimą ateities kartoms. Siekis palikti palikimą skatina vyresnio asmens refleksiją apie visumos jausmą, susiejant gyvenimo tęstinumą, prasmę ir tikslą, ir ieškant būdų kaip reikšmingai prisidèti prie pasaulio savo indèliu (Russell, 2008). Generatyvumo tyrimai iš socialinès gerontologijos 
perspektyvos susieja tęstinę intensyvią veiklą vyresniame amžiuje su (profesinio) identiteto tęstinumu ar atsidavimu socialiai reikšmingai elgsenai (Stergios ir Carruthers, 2002; Warburton ir Gooch, 2007; Borrero ir Kruger, 2015). Stergios ir Carruthers (2002) savo tyrimais nustate, kad tęstinis įsitraukimas i veiklą, susijusią su turèta profesija, yra sietinas su identiteto tęstinumu. Warburton ir Gooch (2007) sieja dalyvavimą savanoriškoje veikloje su "ekologiniu identitetu". Borrero ir Kruger (2015) atliktas i pensiją išèjusių profesionalių moterų tyrimas nustatė reikšmingus identiteto komponentus nuosekliai išliekančius pereinant prie savanoriškos ar darbinès veiklos jau būnant pensijoje: ieškojimas galimybių daryti teigiamą įtaką kitų žmonių gyvenimui ir "būti vertingu pasauliui" (323 p.). Aktyvi tęstinè veikla vyresniame amžiuje taip pat gali būti pateisinta "užsièmimo etika" (Choi, 2009), kuomet vyresni suaugusieji įsitraukia ị savanorišką veiklą kaip socialiai svarbų etišką elgesị. Pavyzdžiui, Golding ir Foley (2017), tyrinėdami skirtingų kartų atstovų mokymąsi kartu neformalioje bendruomenès aplinkoje, priejjo išvados, jog vyresnio amžiaus vyrai įsitraukia i mokymąsi per dalyvavimą mentorystėje, bendruomenèje dalydamiesi savo igūdžiais su atsiribojusiais jaunuoliais. İsitraukimas $\mathfrak{i}$ generatyvią veiklą tampa mokymosi antecedentu, kadangi vyresnis žmogus tokiam įsitraukimui priskiria ypatingą svarbą (Field, 2003), ir siekia gerai atlikti generatyvumo veikloje prisiimtus vaidmenis (Borrero ir Kruger, 2015).

Ankstesnèje patirtyje igyta kompetencija. Mokymosi prasmė vyresniame amžiuje yra siejama su kasdienès veiklos kompetencijomis ir asmeniniais pasiekimais (Lysack ir Steipke, 2002; Pinquart, 2002; Stergios ir Carruthers, 2002). Pinquart (2002) tvirtina, kad aukštas kompetencijos lygis skatina atlikti veiklą ir lemia jos sėkmę, kai tokia veikla yra laikoma gyvenimo tikslo šaltiniu (Pinquart, 2002). Vyresnių suaugusiujų issitraukimas i generatyvumą yra siejamas su profesinès kompetencijos išsaugojimu (Lysack ir Steipke, 2002) ir tolesniu savo profesinès erudicijos ir igūdžiu tobulinimu (Stergios ir Carruthers, 2002). Kompetencija gali slypèti vyresnio žmogaus išmintyje, kurią jis igijo per gyvenimo patirti (Golding ir Foley, 2017). Golding ir Foley (2017) mentorystès tyrimas parodé, kad generatyvi elgsena reikalauja iš vyresnių žmonių būti "šiuolaikiškais savo pasaulěžiūroje remiantis žiniomis ir išmintimi, kuri susiformavo savaime per gyvenimo patirtis" (56 p.). James ir Bates (2009) sukurta generatyvaus buvimo seneliu koncepcija atkreipia demesi $\mathfrak{i}$ tai, kaip senstantys vyrai kuria santykius su vaikaičiais remdamiesi senelio vaidmens ir veiklos suvokimu suformuotu mokantis is ankstesnių kartų (James ir Bates, 2009; Bates ir Goodsell, 2013). Narushima (2000) išskiria svarbų savanoriškos veiklos vaidmeni - suteikti palankią aplinką "gyvenimo apžvalgai” kaip nuolatiniam gvildenimui savęs ir kitų, siekiant vientiso savo patirties suvokimo, kuris padėtų vyresniems žmonèms geriau suprasti save, savo tikslus ir gyvenimo prasmę.

Socialinès aplinkos įtaka. Tabuchi ir kolegos (2015) tyrė jaunesnių kartų žmonių požiūrị i vyresnių šeimos narių generatyvumą, ir nustatė, kad pozityvi sąveika tarp kartų ir suvokiamas pripažinimas teigiamai ịtakoja generatyvumo formavimąsi, kai tuo tarpu suvokiamas atmetimas gali neigiamai paveikti generatyvumo raidą. Vyresnio amžiaus besimokančiųjų generatyvumo siekiai gali implikuoti savitarpiškumą, leidžiantị jaunesnei kartai padèti savo tèvams ir seneliams mokytis naudotis technologijomis (Russell, 2007). Krašovec ir Gregorčič (2017) savo darbe, kuriame tyrè mokymąsi per dalyvavimą bendruomenèje Slovėnijoje, teigia, jog bendruomenè gali tapti mokymosi erdve, suteikiančia galimybes dalintis elgsena ir vertybėmis tarp kartų, joms dalyvaujant demokratijos procesuose. İsitraukimas ị socialinị aktyvumą suteikia vyresniems suaugusiems socialinę kolektyvinę mokymosi aplinką leidžiančią "plètoti savo kūrybiškumą, kritinị mąstymą, savęs išlaisvinimo jausmą, ir savo gerovę" (Narushima, 2005, 41 p.). Pinquart (2002) gyvenimo tikslo vyresniame amžiuje metaanalizè, atlikta remiantis dideliu kiekiu empirinių tyrimų, parodè, kad gyvenimo tikslas daugeliu atvejų yra siejamas su socialine integracija, ir ypač santykių kokybe. Socialinių ryšių su šeima ir draugais kokybė suteikia daugiau galimybių vyresniems žmonėms būti naudingais ir skatina veiklas, kurios tampa gyvenimo tikslo šaltiniu (Pinquart, 2002, 93 p.). Santykių, susijusių su priklausymu, savitarpio ir moraliniais ịsipareigojimais, vertingumas skatina vyresnius žmones "prisiimti atsakomybę už dalijimąsi, indèli ir dalyvavimą siekiant didesnio gèrio sau ir kitiems" (Russell, 2007, 379 p.). Tačiau reikia pažymėti, jog kai kurių tyrimų rezultatai rodo, kad šeimos vaidmuo vyresnio žmogaus gyvenime gali būti periferinis, kuomet vyresnis žmogus nesuvokia šeimos kaip svarbaus instrumentinès ar emocinès socialinès paramos šaltinio (Birrer-Hardwick ir Greenwood, 2017). Kaip 
parodė Neikrug ir kolegų (1995) Izraelyje duomenys, gauti tiriant besimokančius labai senus žmones, vyresni suaugusieji gali labiau domètis savo pačių gyvenimo planavimu ir tvarkymu, o ne atsakomybe šeimai, rūpinimusi vaikais, vaikaičiais ar provaikaičiais. Galima teigti, kad reikšmès perkèlimas i generatyvumo vaidmenis savo artimiausioje šeimos ir draugų aplinkoje suteikia pagyvenusiam žmogui daugiau galimybių tikslingai veikti ir įveikti iššūkius, kylančius iš naujų vaidmenų. Savo ruožtu įsitraukimas ị veiklas, kurios reikalauja ịgyti naujas kompetencijas ar toliau tobulinti savo gebejjimus, skatina asmeninį tobulèjimą.

\section{Generatyvumo kontekste vykstančio vyresnio amžiaus suaugusiųjų mokymosi proceso komponentai}

Informuoto dalyvavimo motyvacija. Informuotas dalyvavimas su generatyvumu siejamoje veikloje išryškèja kaip reikšmingas vyresnio amžiaus žmonių mokymosi motyvacijos faktorius. Mokymąsi gali motyvuoti noras prisidèti prie bendruomenès veiklos, siekiant ją pagerinti ateities kartoms (Lear, 2013; Parisi et al., 2009). Lear (2013) tvirtina, kad mokymuisi vyresnius žmones motyvuoja stiprios generatyvumo paskatos - mokytis išreikšti save generatyvumo veikloje. Vyresnių žmonių mokymasis dalyvaujant savanorystejje edukacinès ar mentorystès veiklos forma yra motyvuotas noro padėti vaikų akademiniam ir asmeniniam tobulejimui (Parisi et al., 2009), suprasti šiuolaikinius vaikus, gilinantis ị jų patiriamas problemas (Stergios ir Carruthers, 2002). Krašovec ir Gregorčič (2017) teigia, kad įsitraukdami ị bendruomenès veiklą, vyresnio amžiaus žmonès gauna galimybę sužinoti apie jaunesnes kartas ir jų vertybes. Mokymosi motyvacijos faktoriai gali pasireikšti kaip poreikis suvokti generatyvumo veiklos paskirti (Stergios ir Carruthers, 2002; Krašovec ir Gregorčič, 2017), noras sužinoti apie konkrečią problemą ar panaudoti savo žinias ir ịūdžius (Stergios ir Carruthers, 2002; Bradley, 2003; De Espanes at al., 2015). Bradley (2003, 49 p.) atkreipia dèmesį, kad mokymosi galimybès turi atitikti vyresnio žmogaus lūkesčius ,išmokti naujo igūdžio ar veiklos, sugrį̌ti prie buvusios patirties, ar perduoti žinias kitai kartai“. Profesinio identiteto tęstinumas motyvuoja vyresnius žmones tęsti veiklą srityje susijusioje su buvusia profesija, kad galètų pritaikyti ekspertines žinias igytas profesinès karjeros laikotarpiu (Stergios ir Carruthers, 2002). Krašovec ir Gregorčič (2017) tyrime išryškejjo mokymosi elementas, kildinamas iš santykių tarp kartų, apimantis konstruktyvios diskusijos žinių tobulinimą, gebėjimus priimti kolektyvinius sprendimus, veikti komandoje ir bendradarbiauti, pasiekti bendrą sutarimą, spręsti konfliktus, stiprinti bendradarbiavimą tarp kartų.

Igalinimas. Igalinantis vyresnių žmonių mokymosi pobūdis gali būti išreikštas per emancipacijos, asmeninio tobulëjimo ir kompetencijų tobulinimo paradigmas. Emancipacinę paradigmą plačiai tyrinèja Narushima $(1999,2004)$ vyresnių žmonių savanorystės bendruomenèje ir socialinio aktyvumo veikloje. Savo darbe, tiriančiame socialinio aktyvumo ịtaką moterų mokymuisi vyresniame amžiuje Narushima (2004) analizuoja mokymąsi vyresniame amžiuje iš tarpdisciplininès feministinès perspektyvos, apimančios suaugusiojo raidą, kritinę gerontologiją ir moterų studijas. Tyrimo rezultatai rodo, kad ịsitraukimas ị bendradarbiavimą ir kūrybiškumą skatinančias politines veiklas skatina mokymąsi ir sustiprina gebejjimą veikti. Dalyvavimas veiklose gali būti vertinamas kaip emancipacija, kadangi vyresnis žmogus ịsitraukia ị mokymąsi kaip "tęstinị saviaktualizacijos ir išsilaisvinimo procesą" (Narushima, 2004, 38 p.). Krašovec ir Gregorčič (2017) nustatè, kad emancipacinis mokymosi pobūdis yra būdingas vyresnių žmonių pilietinei veiklai. Vyresnius žmones mokytis motyvuoja poreikis siekti asmenybès augimo (Narushima, 1999; Bradley, 2003; Warburton ir Gooch, 2007; Lear, 2013), savirealizacijos (Lear, 2013) ir saviaktualizacijos (Narushima, 2004). Narushima (2004) tvirtina, kad tobulejjimo vyresniame amžiuje tikslai siejasi su psichologiniu ir dvasiniu augimu ir saviaktualizacija formuojantis ego vientisumą ir „transcendenciją” (39 p.). Vyresnių suaugusiųų asmenybės raida ir augimas atsispindi "adaptaciniame savo patirties suvokimo procese, siekiant tvirtai integruoti save santykyje su kitais ir visuomene" (Narushima, 1999, 19 p.). Narushima (2004) teigia, kad jos tyrime moterys stengèsi tapti "kažkuo", per "tikrosios savęs ieškojimą ir dvasinị augimą" nepaisant patiriamos amžiaus diskriminacijos (39 p.). Vyresnius žmones mokytis motyvuoja ieškojimas "naujo gyvenimo būdo siekiant suderinti sudètingus ir dažnai 
prieštaringus jiems keliamus reikalavimus" (Lear, 2013, 380 p.). Narushima (2000) sieja savanorystę bendruomenès labui su sunkumu ịveikimo, saviraiškos, prisidejimo savo indèliu, itakos stiprinimo, transcendencijos poreikiais. Kompetenciju tobulinimas generatyvumo veiklose yra svarbus žmogaus igalinimo faktorius vyresniame amžiuje (Lysack ir Steipke, 2002; Kruse ir Schmitt, 2012; Villar ir Serrat, 2014). Lysack ir Steipke (2002) tyrimas parodè, kad vyresnès moterys konstruoja ir komunikuoja savo ịvaizdi kaip kompetentingos asmenybès "moterų sferoje" (tradiciškai moterims priskiriamose užduotyse) siekdamos reprezentuoti save kitiems. Siekdamos išlaikyti norimą darbinès veiklos lygi, šioje produktyvioje srityje moterys išmoksta būdų kaip kompensuoti tas veiklas, kurių jos jau nebepajègia atlikti, naujai apibrèždamos ir atstatydamos savo "profesinio aš" ribas taip, kad atitiktų esamą situaciją - sumažindamos lygi arba apribodamos veiklų kiekị. İsitraukdami i generatyvumą, vyresni žmonės formuojasi gyvenimui svarbias kompetencijas: fizines ir kognityvines strategijas, žinių sistemas, etinius vertinimus, pasirengimą prisiimti atsakomybę už save, kitus ir visuomenę (Kruse ir Schmitt, 2012). Gyvenimo kompetencijos formuojasi efektyviai ịveikiant senèjimo iššūkius, tame tarpe praktines, psichologines, tarpasmenines ir etines problemas ( 2 p.).

Savaiminio mokymosi patirčių įvairovè. Didelè dalis tyrimų rodo, kad savaiminis mokymasis yra pagrindinis vyresnių suaugusiųų mokymosi tipas generatyvumo kontekste (Duguid et al., 2013; Krašovec ir Gregorčič, 2017). Duguid ir kolegos (2013) teigia, kad savaiminis mokymasis yra objektyvas, per kurị turi būti tiriama savanorių mokymosi veikla. Savaiminiam mokymuisi būdingas aktyvumas ir autentiškumas (Krašovec ir Gregorčič, 2017), implikuotas, patirtinis pobūdis (Lear, 2013). Schugurensky ir Myers (2008), tirdami vyresnių suaugusiujų mokymąsi dalyvaujant demokratijos procesuose (vietinès savivaldos) nustatè, kad mokymasis dažniausiai yra neišreikštas (numanomas) ir nèra sąmoningai planuotas, nes dalyviai mokosi veiklos metu ir stebėdami politinius procesus. Patirtinis mokymosi pobūdis vyresnių žmonių mokymesi atskleidžiamas ir kitų mokslininkų darbuose (Narushima, 2000; Piercy et al., 2011). Nemažai tyrimų demonstruoja savivaldų mokymosi pobūdį kaip reikšmingą mokymosi vyresniame amžiuje ypatumą (Narushima, 2000; Roberson, 2005; Warburton ir Gooch, 2007; Schugurensky ir Myers, 2008). Mokymasis gali vykti kaip savivaldus procesas, kuomet dalyviai sąmoningai mokosi apie tam tikrus dalykus (Serrat et al., 2016) arba kaip atsitiktinis (neplanuotas, tačiau sąmoningas), kuomet dalyviai geba identifikuoti, jog vyksta mokymasis (Schugurensky ir Myers, 2008; Duguid et al., 2013; Serrat et al., 2016). Narushima (2000) teigia, kad vyresni žmonès ịsitraukia ị savivaldų mokymąsi, problemų sprendimą ir komunikavimą su būdingomis patirtinio ir holistinio mokymosi patirtimis, padedančiomis plèsti konkrečias žinias apie socialinius klausimus ir savęs pažinimo žinias. Roberson (2005) generatyvumo veiksmai motyvuoja vyresnius suaugusius naudoti savivaldų mokymąsi kaip priemonę, teikiančią reikšmingą naudą kitiems žmonėms (Sears, 1989), padedančią patenkinti šeimos poreikius (Roberson, 2005).

Vyresnių žmonių mokymosi generatyvumo kontekste literatūra demonstruoja mokymosi paradigmų, kuriomis remiantis analizuojamas mokymosi procesas, ịvairovę: instrumentinis mokymasis (Narushima, 2000, 2005; Serrat et al., 2016), socialinis mokymasis (Narushima, 2004, 2005; Serrat et al., 2016; Krašovec ir Gregorčič, 2017; Yuan et al., 2018), kritinis ir politinis mokymasis (Serrat et al., 2016), komunikacinis mokymasis (Narushima, 1999, 2000; Schugurensky ir Myers, 2008; Piercy et al., 2011; Lear, 2013; Golding ir Foley, 2017; Krašovec ir Gregorčič, 2017); transformuojantis mokymasis (Narushima, 2005; Warburton ir Gooch, 2007; De Espanes et al., 2015). Instrumentinis mokymasis apima savaiminio mokymosi veiklos ịvairovę (Narushima, 2005) ir generatyvumo veiklai reikalingų igūdžių igijimą ir tobulinimą: praktinius ir techninius igūdžius (Serra et al., 2016), komunikacinius igūdžius (Narushima, 2005; Serrat et al., 2016), organizacinius/vadybinius ịgūdžius, tarpasmeninius igūdžius (Narushima, 2005). Socialinis mokymasis yra siejamas su "komunikacija, pasitikejjimu, pagarba, užuojauta, atvirumu" (Serrat et al., 2016, 171 p.). Vyresniam asmeniui dalyvaujant demokratiniuose procesuose, socialinio mokymosi elementai apima gebejjimą klausytis ir gerbti kitų nuomonę, solidarumo jausmą, socialinès harmonijos pripažinimą, integraciją i bendruomenę, mokymąsi apie bendruomenės ir santykių vertę (Serrat et al., 2016), kitų žmonių suvokimą ir pagalbą, bendrumo jausmą (Krašovec ir Gregorčič, 2017), bendrą planavimą, dalijimąsi žiniomis, mokymąsi apie ịsitraukimą ị bendruomenès veiklą (Krašovec ir Gregorčič, 2017). Yuan ir kolegos (2018) pristato socialinio mokymosi galimybes, kurias suteikia įsitraukimas ị koprodukavimą 
(angl. coproduction), apimantị intelektualinę veiklą dalijantis patirtimi, diskusijas ịvairiomis temomis. Kritinis mokymasis dalyvaujant politinejje ir pilietinèje veikloje apima savo ir visuomenès vertybių, prioritetų ir politikos analizavimą (Serrat et al., 2016). Serrat ir kolegos (2016) apibrèžia politini mokymąsi kaip "filosofini ir praktini tobulëjimą santykyje su politiniu dalyvavimo kontekstu, apimančiu sustiprintą socialinès ir politinès realybès savo bendruomenèje supratimą, kolektyvinių veiksmų vertinimą, sustiprèjusi gebejjimą atkakliai ginti savo teises” (177 p.). Komunikacinis mokymasis gali būti ryškus savanoriškoje veikloje, kuomet sąveikaujama su kitais, sprendžiamos problemos, ir gaunama nauja informacija (Narushima, 2000). Savanoriškos veiklos paskatintas komunikacinis mokymosi pobūdis gali padèti vyresniam žmogui spręsti senèjimo dilemas ir pakeisti senas nuostatas ị save ir pasauli (Narushima, 1999). Schugurensky ir Myers (2008) nurodo, jog kalbejjimasis su žmonėmis, turinčiais patirties ir erudicijos konkrečiais klausimais, nusimanančiais apie senų žmonių problemas buvo dažniausiai pasitelkiama strategija jų tyrimo dalyvių tarpe. Mokymasis vyksta keičiantis patirtimi, nuomonèmis, formuojantis gebejimą tiesiogiai suprasti problemas, ir atvirumą kitokiems žmonėms (Krašovec ir Gregorčič, 2017), draugyste, pagarba ir prisirišimu grịstus santykius su jaunesne karta (Golding ir Foley, 2017). Transformuojančio mokymosi elementai pastebimi generatyvumo veikloje rodo asmenybès keitimąsi (Narushima, 2005; Warburton ir Gooch, 2007; De Espanes et al., 2015), kuomet individui tenka spręsti generatyvumo ir stagnacijos konfliktą (Erikson et al., 1986). Mokymesi pasireiškiantys transformuojantys mechanizmai gali suteikti galimybes vyresniems žmonėms išlaikyti savigarbą ir gerovès pojūtị (Narushima, 2005), transformuoti rūpinimąsi ateities kartomis ì generatyvumu grịstą elgseną (De Espanes et al., 2015), formuoti grandgeneratyvumą kaip jaunų žmonių mokymą ir mentorystę (Warburton ir Gooch, 2007).

Refleksija apie mokymąsi. Vyresni žmonès suvokia, kad mokymasis vyksta dalyvaujant veiklose (Warburton ir Gooch, 2007; Krašovec ir Gregorčič, 2017), tačiau jiems gali būti sunku tai išreikšti žodžiais (Schugurensky ir Myers, 2008). Dažnai vyresni žmonės gali neįžvelgti ir neịvardinti savo mokymosi, vykstančio generatyvumo kontekste, kadangi mokymosi patirtis gali pasireikšti ir kaip sąmoningas mokymasis, ir kaip nesąmoningas mokymasis, kuris gali tapti sąmoningu tolesnès refleksijos pagalba (Duguid et al., 2013). Kritinę refleksiją kaip mokymosi patirtị gali paskatinti vyresnių žmonių noras palikti savo indèlį būsimoms kartoms (Pfahl, 2012). Mokymasis gali tapti raidos vyresniame amžiuje dalimi, kuomet žmogus objektyvizuoja ir reflektuoja savo patirtis, jas apibendrina ir panaudoja (Parisi et al., 2009), suvokia jos prasmę, ir konstruktyviai veikia siekdamas pokyčio, integruodamas "gyvenimo patyrimus ị prasmingą naratyvinị palikimą" (Pfahl, 2012, 81 p.).

\section{Mokymosi generatyvumo kontekste reikšmė vyresnio amžiaus žmonių gyvenime}

Asmenybės augimas. Generatyvumą tiriančiuose darbuose pateikiama įrodymų, kad mokymasis generatyvumo kontekste daro ịtaką asmenybès augimui (Narushima, 1999; Warburton ir Gooch, 2007; Piercy et al., 2011). Savanoriškoje veikloje vykstantis mokymosi procesas leidžia vyresnio amžiaus žmonèms įsitraukti i konstruktyvų saviintegracijos, savęs tobulinimo ir saviaktualizacijos procesą (Narushima, 1999). Urrutia ir kolegų atliktas (2009) vyresnio amžiaus moteru generatyvumo tyrimas Argentinoje pateike ịrodymų, kad mokymasis vyksta atliekant socialinius vaidmenis už šeimos ribų, ir tokio mokymosi rezultatas gali būti išreikštas kaip asmenybès integralumo didèjimas. Warburton ir Gooch (2007) nustatè, kad mokymosi, vykstančio individui dalyvaujant savanoriškoje veikloje aplinkos apsaugoje rezultatas gali būti ekologiškai orientuotos tapatybès formavimas. Piercy ir kolegu (2011) darbas demonstruoja savanoriškos veiklos patirties ịtaką egzistencinès prasmès ieškojimui, pasaulio kompleksiškumo suvokimui ir emocinio atsparumo formavimuisi. Mokymasis per savanorystę gali skatinti asmenybės augimą kaip individo autonomiškumą, "kultūrinị generatyvumą", "ego-integralumą" ir transcendenciją (Narushima, 2000). Tai atitinka vėlyvojo suaugusiojo amžiaus raidos uždavinius pristatytus (Erikson et al.,1986; Kotre, 1998). Asmenybès augimas gali atsispindèti išminties kaip "pakitusios asmeninès perspektyvos su sumažejusiu materializmu ir susitelkimu ị save, didesniu kultūrinių skirtumų vertinimu, bei egzistencinès prasmès suradimu tarnavime kitiems" susiformavimu (Piercy et al., 2011, 550 p.). Mokslinèje literatūroje išminties sąvoka plačiai siejama su mokymusi vyresniame amžiuje, vertinant kaip mokymosi rezultatą, kuris apima žinių apdorojimą, jų 
pritaikomumo suvokimą, pažintinius pajègumus ir asmeninę įžvalgą, gebèjimą integruoti ankstesnes ir dabartines žinias, ir jų potencialaus poveikio ateities pasiekimams suvokimą (Parisi et al., 2009). Išmintis gali būti sustiprinta sąveikoje su kitomis kartomis mokant ir būnat mentoriumi jaunesnei kartai (Parisi et al., 2009). Asmenybès augimą gali rodyti formavimas naujos, autentiškesnès tapatybės, vedančios ị senatvę (Lear, 2013, p. 389). Villar (2012) tvirtina, kad "generatyvumas reiškia asmeninị tobulējimą, kadangi generatyvumo veikla ir tikslai suteikia žmonių gyvenimui prasmę, ir tarnauja kaip būdas sustiprinti jų kompetencijas, igūdžius ir interesus, kurie savo ruožtu plečia su generatyvumu susijusių prieinamų veiklų skalę" (Villar, 2012, 1098 p.).

Asmeninès kompetencijos ugdymas. Asmeninès kompetencijos tobulëjimą gali skatinti ịsitraukimas ị generatyvumo veiklas mokant jaunają kartą (Stergios ir Carruthers, 2002; Parisi et al., 2009), ar rūpinantis savo šeima (Villar et al., 2012). Mokymosi rezultatai gali pasireikšti kaip tarpasmeninių santykių, lyderystès, mentoriaus gebėjimų tobulëjimas (Parisi et al., 2009), socialiniam solidarumui, bendradarbiavimui tarp kartų, socialinei harmonijai reikalingų kompetencijų igijimas (Krašovec ir Gregorčič, 2017), bendrumo ir bendruomeniškumo jausmas, gilesnis supratimas apie santykių su kaimynais kūrimo svarbą susiduriant su skirtumais ir konfliktais, pasitikejjimo savimi ir atkaklumo jausmas (Serrat et al., 2016). Mokymosi rezultatai siejasi su veiklos pobūdžiu ir socialine realybe, instrumentinių, tarpasmeninių, politinių, komunikacinių gebejjimų tobulinimu ir politiniu veiksmingumu (Duguid et al., 2013), ir gali pasireikšti kaip pokyčiai, vykstantys dalyvių požiūriuose, žiniose, igūdžiuose (Lear, 2013; Serrat et al., 2016), ar net anksčiau neugdytų gebejjimų suvokimas (Lear, 2013). Schugurensky ir Myers (2008) nustatė, kad vyresnių žmonių suvokime pokyčiai gali labiau asocijuotis su konkrečios informacijos ịijimu, naujos įžvalgos ar požiūrio susiformavimu nei su kompetencijų igijimu.

Savo vaidmens ịtvirtinimas. Vyresni žmonès gali ịžvelgti mokymesi didesnę vertę nei asmeninis augimas - tai gali būti vertinama kaip "asmeninès emancipacijos jèga" (Field, 2003, 153 p.). Mokymasis atsispindi emancipacijos pokyčiuose, kuriuos patiria vyresni žmonès dalyvaudami ivvairiose su generatyvumu susijusiose srityse (Narushima, 2000; Stergios ir Carruthers, 2002; BirrerHardwick ir Greenwood, 2017). Isitraukimas i generatyvumą leidžia vyresnio amžiaus savanoriams geriau suvokti savo vaidmeni santykyje su kitais ir visuomene (Narushima, 2000) ir skatina savo asmenybès pajautimą (Stergios ir Carruthers, 2002), padeda surasti būdus tobulinti ir gerinti santykius tarp kartų (Bates ir Taylor, 2013). Mokymasis ir savanorystė gali iššaukti pokyčius vyresnio asmens elgsenoje ir požiūryje, igyjant daugiau užtikrintumo (Narushima, 2000) ir prisidèti prie vyresnių suaugusių veiksnumo savo kontekstuose ir socialiniuose tinkluose (Villar, 2012). Lear (2013) teigimu, mokymasis politinio dalyvavimo aplinkoje gali reikšti naujo sąmoningumo apie save, savo gyvenimą ir pasauli susiformavimą, išaugusi pasitikejjimą savimi ir veiksnumą. Villar (2012) nurodo, kad vyresnio amžiaus suaugusių generatyvumas pasireiškia kaip "savo indėlio įdejjimas ị aplinkos, kurioje vyresni žmonès veikia, palaikymą ir gerinimą stiprinant socialines institucijas, turtinant socialinius tinklus, ir užtikrinant tęstinumą iš kartos į kartą“ (1095p.). İsitraukimas ị mokymąsi generatyvumo kontekste leidžia vyresniems žmonėms sustiprinti tam tikras asmenines vertybes, rodyti pavyzdi kitiems (Birrer-Hardwick ir Greenwood, 2017) ir daro teigiamą poveikį amžiaus adaptacijos procesams (Villar ir Serrat, 2014; Kruse ir Schmitt, 2012). Narushima (1999) apibrèžia mokymąsi per generatyvumą kaip "progresyvų pilno individo potencialo realizavimą", vedantị prie "gilesnio visuomenès suvokimo, ir aukštesnio socialinès integracijos lygio" (19 p.).

\section{Išvados}

1. Literatūros apžvalgos atlikimo procesas parodè, kad pastaraisiais dešimtmečiais pradèta aktyviau tyrinèti generatyvumą vyresniame amžiuje, tačiau dar yra nedaug darbų, skirtų tirti savaiminio mokymosi procesus, vykstančius vyresnio amžiaus žmonèms ịsitraukiant i generatyvumą. Empiriniais tyrimais grịstų darbų apžvalga leidžia teigti, kad mokymasis kaip asmeninis tobulèjimas yra natūrali neatsiejama ịsitraukimo ì generatyvumą dalis, skatinanti informuotą dalyvavimą ir kompetencijų tobulinimą siekiant generatyvumo tikslų. Santykis tarp generatyvumo ir mokymosi gali būti išreikštas kaip „mokymasis dèl generatyvumo ir generatyvumo pagalba” paradigma. Kaip rodo 
mokymosi ir įsitraukimo ị generatyvumą ryšio dinamika, generatyvumo veikla gali stimuliuoti tolesnio mokymosi poreikius, kai tuo tarpu mokymasis savo ruožtu gali stimuliuoti vyresnių žmonių įsitraukimo ị generatyvumą kokybę.

2. Literatūros apžvalga leido išskirti mokymosi vykstančio generatyvumo kontekste būdingus bruožus, apimančius faktorius ịtakojančius mokymąsi, pagrindinius mokymosi proceso ypatumus ir mokymosi reikšmę vyresnių žmonių gyvenimui. Vyresnio amžiaus žmonių ịsitraukimas ị generatyvumą, ankstesnio mokymosi kompetencija (patirtis) ir socialinè aplinka daro įtaką mokymuisi. Galima išskirti šiuos generatyvumo kontekste vykstančio vyresnio amžiaus suaugusiujų mokymosi proceso ypatumus: informuotu dalyvavimu grịsta motyvacija, igalinimas, savaiminio mokymosi patirčių ivvairovė, refleksija. Asmenybès augimas, asmeninès kompetencijos tobulinimas, savo vaidmens įtvirtinimas yra mokymosi pasekmès, darančios įtaką vyresnių suaugusiųjų gyvenimui.

3. Generatyvumas suteikia svarbią tyrimo perspektyvą analizuojant mokymąsi vyresniame amžiuje kaip savaiminio mokymosi procesą. Šioje perspektyvoje atliekami vyresnio amžiaus žmonių mokymosi tyrimai gali pasiremti generatyvumo ir mokymosi sąsajų dinamika. Integracinis tokios perspektyvos pobūdis leidžia susieti motyvacinius, elgsenos, naratyvinius generatyvumo aspektus su mokymosi vyresniame amžiuje motyvacija, strategijomis ir rezultatais.

\section{Literatūra}

1. Bates, J.S., \& Goodsell, T.L. (2013). Male kin relationships: Grandfathers, grandsons and generativity. Marriage and Family Review, 49(1), 26-50. https://doi.org/10.1080/01494929.2012.728555

2. Birrer-Hardwick, R., \& Greenwood, R.M. (2017). Older adults' social capital and generative activity in rural Ireland. Community Psychology in Global Perspective, 3(1), 15-32. https://doi.org/10.1285/i24212113v3i1p15

3. Borrero, L., \& Kruger, T.M. (2015). The nature and meaning of identity in retired professional

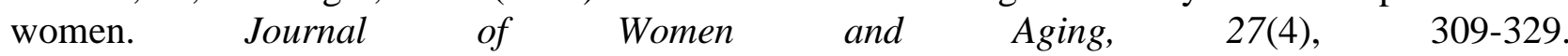
https://doi.org/10.1080/08952841.2014.950141

4. Bradley, D. (2003). A reason to rise each morning: The meaning of volunteering in the lives of older adults. Generations, 23(4), 45-50.

5. Choi, I. (2009) The meaning of older adults' peer teaching: A phenomenological study. Educational Gerontology, 35(9), 831-852. https://doi.org/10.1080/03601270902973573

6. De Espanes, G.M., Villar, F., Urrutia, A., \& Serrat, R. (2015). Motivation and commitment to volunteering in a sample of Argentinian adults: What is the role of generativity. Educational Gerontology, 41, 149-161. https://doi.org/10.1080/03601277.2014.946299

7. Duguid, F., Mundel, K., \& Schugurensky, D. (2013). Volunteer work and informal learning: A conceptual discussion. In F. Duguid, K. Mundel, \& D. Schugurensky (Eds.), Volunteer work, informal learning and social action (pp. 17-36). Rotterdam, Netherlands: Sense. https://doi.org/10.1007/978-94-6209-233-4

8. Erikson, E.H. (1963). Childhood and society (2nd ed.). New York: Norton.

9. Erikson, E.H., Erikson, J., \& Kivnick, H.Q. (1986). Vital involvement in old age. New York: W.W.Norton.

10. Field, J. (2003). Civic engagement and lifelong learning: Survey findings on social capital and attitudes towards learning. Studies in the Education of Adults, 35(2), 142-156. https://doi.org/10.1080/02660830.2003.11661479

11. Flynn, P.T. (2001). Meaningful activity in later life. Activities, Adaptation and Aging, 24(3), 71-88. https://doi.org/10.1300/J016v24n03_05

12. Golding, B. G., \& Foley, A. (2017). Men and boys: Sharing the skills across generations. Journal of Intergenerational Relationships, 15(1), 52-63. https://doi.org/10.1080/15350770.2017.1260362

13. Grant, M.J., \& Booth, A. (2009). A typology of reviews: An analysis of 14 review types and associated methodologies. Health Information and Libraries Journal, 26, 91-108. https://doi.org/10.1111/j.1471-1842.2009.00848 
14. James S., \& Bates, J.S. (2009) Generative grandfathering: A conceptual framework for nurturing grandchildren. Marriage \& Family Review, 45(4), 331-352. https://doi.org/10.1080/01494920802537548

15. Jones, B.K., \& McAdams, D.P. (2013). Becoming generative: Socializing influences recalled in life stories in late midlife. Journal of Adult Development, 20, 158-172. https://doi.org/10.1007/s10804-013-9168-4

16. Kleiber, D., \& Nimrod, G. (2008). Expressions of generativity and civic engagement in a "Learning in Retirement" group. The Journal of Adult Development, 15, 76-86. https://doi.org/10.1007/s10804-008-9038-7

17. Kotre, J. (1998). The generative way of life: A practical perspective. Paper presented at the meeting of the study of Public Philosophy. Kyoto, Japan. Retrieved May 16, 2017, from https://ovop.pw/18q.pdf

18. Krašovec, S.J., \& Gregorčič, M. (2017). Intergenerational exchange of knowledge, skills, values and practices between self-organized active citizens in Maribor, Slovenia. Australian Journal of Adult Learning, 57(3), 401-420. Retrieved September, 26, 2019, from https://files.eric.ed.gov/fulltext/EJ1163876.pdf

19. Kruse, A., \& Schmitt, E. (2012). Generativity as a route to active ageing. Current Gerontology and Geriatrics Research, ol. 2012, Article ID 647650, 9 pages. https://doi.org/10.1155/2012/647650

20. Lear, G. C. (2013). Ready for action and civic engagement: Resilient third age women learners in rural Australia. Australian Journal of Adult Learning, 53(3), 375-393.

21. Lysack, C.L., \& Steipke, H.L. (2002). Communicating the occupational self: A qualitative study of oldest-old American women. Scandinavian Journal of Occupational Therapy, 9, 130-139. https://doi.org/10.1080/11038120260246969

22. McAdams, D. P., \& de St. Aubin, E. (1992). A theory of generativity and its assessment through self-report, behavioral acts, and narrative themes in autobiography. Journal of Personality and Social Psychology, 62(6), 1003-1015. https://doi.org/10.1037/0022-3514.62.6.1003

23. McAdams, D. P., Hart, H. M., \& Maruna, S. (1998). The anatomy of generativity. In D. P. McAdams \& E. de St. Aubin (Eds.), Generativity and adult development: How and why we care for the next generation (pp. 7-43). Washington, D.C.: American Psychological Association. https://doi.org/10.1037/10288-001

24. Narushima, M. (1999). Transformative learning theory and the study of aging: The implication of case studies of older volunteers. Paper presented at the annual meeting of the American Educational Research Association. Montreal, Quebec.

25. Narushima, M. (2000). Transformation toward what end? Exploring later life learning in community volunteering. Proceedings of Adult Education Research Conference. Vancouver, BC, Canada. Retrieved October 21, 2018, from http://newprairiepress.org/aerc/2000/papers/58

26. Narushima, M. (2004). A gaggle of raging grannies: The empowerment of older Canadian women through social activism. International Journal of Lifelong Education, 23(1), 23-42. https://doi.org/10.1080/0260137032000172042

27. Narushima, M. (2005). "Payback time": Community volunteering among older adults as a $\begin{array}{llll}\text { transformative } \quad \text { Ageing } \quad \& \quad \text { Society, } & \text { 25, 567-584. }\end{array}$ https://doi.org/10.1017/S0144686X05003661

28. Neikrug, S., Ronen, M., Glanz, D., Alon, T., Kanner, S, \& Kaplan, A. (1995). A special case of the very old: Lifelong learners. Educational Gerontology, 21, 345-355.

29. Parisi, J.M., Rebok, G.W., Carlson, M.C., Fried, L.P., Seeman, T.E., Tan, E.J., Tanner, E.K., \& Piferi, R.L. (2009). Can the wisdom of aging be activated and make difference societally? Educational Gerontology, 35(10), 867-879. https://doi.org/10.1080/03601270902782453

30. Piercy, K. W., Cheek, C., \& Teemant, B. (2011). Challenges and psychosocial growth for older volunteers giving intensive humanitarian service. The Gerontologist, 51, 550-560. https://doi.org/10.1093/geront/gnr013

31. Pinquart, M. (2002). Creating and maintaining purpose in life in old age: A meta-analysis. Ageing International, 27(2), 90-114. https://doi.org/10.1007/s12126-002-1004-2 
32. Ranzijn, R. (2002). The potential of Older adults to enhance community quality of life: Links between positive psychology and productive aging. Ageing International, 27(2), 30-55.

33. Roberson, D.N. (2005). Leisure and learning: An investigation of older adults and self-directed learning. Leisure/Loisir, 29(2), 203-237. https://doi.org/10.1080/14927713.2005.9651330

34. Rubinstein, R.L., Girling, L.M., de Medeiros, K., Brazda, M., \& Hannum, S. (2015). Extending the framework of generativity theory through research: A qualitative study. Gerontologist, 55(4), 548559. https://doi.org/10.1093/geront/gnu009

35. Russell, H. (2007). Learning for being: An ontological and existential approach. International Journal of Lifelong Education, 26(4), 363-384. https://doi.org/10.1080/02601370701417137

36. Russell, H. (2008). Later life: A time to learn. Educational Gerontology, 34, 206-224. https://doi.org/10.1080/03601270701835981

37. Schugurensky, D., \& Myers, J. P. (2008). Informal civic learning through engagement in local democracy: The case of the Seniors' Task Force of Healthy City Toronto. In K. Church, N.Bascia \& E. Shragge (Eds.), Learning through community: Exploring participatory practices (pp. 73-95). London, England: Springer.

38. Sears, E.J.B. (1989). Self-directed learning projects of older adults [Unpublished doctoral dissertation]. Denton: University of North Texas.

39. Serrat, R., Petriwskyj, A., Villar, F., \& Warburton, J. (2016). Learning through political participation: A case study of Spanish elders involved in political organizations. Adult Education Quarterly, 66(2), 169-187. https://doi.org/10.1177/0741713615627013

40. Serrat, R., Villar, F., Giuliani, M.-F., \& Zacares, J.-J. (2017). Older people's participation in political organizations: The role of generativity and its impact on well-being. Educational Gerontology, 43(3), 128-138. https://doi.org/10.1080/03601277.2016.1269541

41. Stergios, C.A., \& Carruthers, C.P. (2002). Motivations of elder volunteers to youth programs. Leisure/Loisir, 27(3-4), 333-361. https://doi.org/10.1080/14927713.2002.9651309

42. Tabuchi, M., \& Miura, A. (2015). Young people's reactions change elderly people's generativity and narratives: The effects of intergenerational interaction on the elderly. Journal of Intergenerational Relationships, 13(2), 118-133. https://doi.org/10.1080/15350770.2015.1026298

43. Tabuchi, M., Nakagawa, T., Miura, A., \& Gondo, Y. (2015). Generativity and interaction between the old and young: The role of perceived respect and perceived rejection. The Gerontologist, 55(4), 537-547. https://doi.org/10.1093/geront/gnt135

44. Tam, M. (2013). A model of active ageing through elder learning: The Elder Academy Network in Hong Kong. $\quad$ Educational Gerontology, 250 39, https://doi.org/10.1080/03601277.2013.750931

45. Urrutia, A, Cornachione, M.A., de Espanes, G.M., Ferragut, L., \& Guzman, E. (2009). The culminating point of generativity in older women: Main aspects of their life narrative. Forum Qualitative Sozialforschung/Forum: Qualitative Social Research, 10(3), Art.1.

46. Villar, F. (2012). Successful ageing and development: The contribution of generativity in older age. Ageing and Society, 32, 1087-1105. https://doi.org/10.1017/S0144686X11000973

47. Villar, F., \& Serrat, R. (2014). A field in search of concepts: The relevance of generativity in understanding intergenerational relationships. Journal of Intergenerational Relationships, 12(4), 381-397. https://doi.org/10.1080/15350770.2014.960352

48. Villar, F., Celdran, M., \& Triado, C. (2012). Grandmothers offering regular auxiliary care for their grandchildren: An expression of generativity in later life? Journal of Women and Aging, 24(4), 292-312. https://doi.org/10.1080/08952841.2012.708576

49. Warburton, J., \& Gooch, M. (2007). Stewardship volunteering by older Australians: The generative response. Local Environment, 12(1), 43-55. https://doi.org/10.1080/13549830601098230

50. Yuan, C.W., Hanrahan, B.V., Rosson, M.B., \& Carroll, J.M. (2018). Coming of old age: understanding older adults' engagement and needs in coproduction activities for healthy ageing. $\begin{array}{llll}\text { Behaviour and Information } & \text { Technology, }\end{array}$ https://doi.org/10.1080/0144929X.2018.1432686 


\title{
LATER LIFE LEARNING IN GENERATIVITY: LITERATURE REVIEW
}

\author{
Salomeja Satiene, Ph.D. \\ Klaipeda State University of Applied Sciences
}

\begin{abstract}
Summary
In the recent decades, in the theory and research of educational gerontology, generativity has been identified as a new perspective to view later life learning. Generativity as a context for informal learning may provide opportunities for older adults to gain competencies needed to achieve their developmental goals at this stage of life. Following Erikson's theory, learning is embedded in an older person's efforts to resolve the generativity-related developmental crisis, which leads to personal growth (Erikson et al., 1986). The developmental goals in later life are associated with personal development as psychological and spiritual growth, and self-actualization. Engagement in generativity is linked with an older person's quest for meaning and desire to leave a legacy for future generations (McAdams et al., 1998). As an inner need, it is expressed in investing in the future through sharing the knowledge and wisdom with succeeding generations, and preserving and handing down traditions and values. The search for ways to significantly contribute to the world may lead to reflection and integrity of life continuity, purpose and meaning. Expressing oneself in generative activity may become a strong motivator for learning as generativity in later life is associated with older people contributing to the development of their social environment with their knowledge and skills. The learning experience may be connected with an older person's engagement in generativity through teaching and mentoring young people, civil participation, productive activity, grandparenting, voluntary activity, or social participation. Engagement in generativity becomes an antecedent of learning in the way an older person aims at competently performing the roles they adopt in their generative environments.

This article presents the results of a literature review based on empirical research studies of generativity and learning in later life published in the past two decades. The aim of the review is to disclose how the context of generativity may influence informal learning in later life. The goals of the study included identifying generativity-related factors which may influence learning, the characteristics of the learning process, and the consequences of learning. Although the scholarship on later life learning indicates that informal learning is a common type of learning in later life, there has been limited research on informal learning of older adults in generativity contexts in the last decades. The review of empirical studies shows that researches provide substantial evidence on learning being an inherent part of older adults' engagement in generativity. Learning stimulates informed participation in generative activities and competence development aiming at achievement of generativity goals. The literature review shows that there is a variety of learning paradigms associated with generativity context: instrumental learning, social learning, critical and political learning, communicative learning, transformative learning. The dynamics of the relationship between generativity and learning shows that generativity may stimulate the need for learning to be continued in later life. Learning may positively affect the quality of older people's engagement in generativity, and enhance their performance. The factors influencing learning include older adults' generative engagement, competences gained in previous learning through career, and the effects of the social environment. Informed generativity motivation, empowerment, informal learning experiences, and reflection are the main characteristics of the learning process. The consequences of generativity-related learning in an older person's life include personal growth, competence development, and establishment of social roles. Generativity may provide an important perspective for research on learning in later life as an informal learning process. The research on older adults' learning carried out in this perspective may focus on the dynamics of generativity and learning. The integrative nature of this perspective allows linking motivational, behavioral, and narrative elements of generativity with the motivation, strategies and outcomes of informal later life learning.
\end{abstract}

Keywords: generativity, older adults, later life learning. 